\title{
The people's own media: Workers representation in Czechoslovak Socialist Television
}

\begin{abstract}
Even though on first sight socialist rule might appear as monolithic and totalitarian with no room for individual agency, people living in socialist societies nevertheless experienced substantial possibilities of self-determination. Especially workers as the socialist vanguard and most privileged societal group had certain spaces to negotiate the conditions of their everyday life with the regime. This paper seeks to identify such spaces of negotiation by analysing the exchanges between Czechoslovak Television (ČST - Československá televize) and its viewers with regard to the role of entertainment in the daily programme throughout the 1960s. Here, the audience's agency contrasts the new media's significance for the Communist Party as a crucial part of ideological education. The paper demonstrates that it was actually the Party's efforts to build a socialist consciousness, which empowered workers to claim self-determination about their leisure time. Letters to the makers of TV programmes thus became an avenue to stake claims for the cultural sovereignty of the people. This reveals a perhaps surprising space of this contest: television programmes and entertainment. In the context of limited parliamentary and public channels for participation, these became an important arena as alternative channels for claiming participation were not available.
\end{abstract}

\section{Introduction}

In socialist states, television was in a difficult position. As "an institution that lived in the intersection of the public and domestic spheres, between top-down attempts at influencing viewers and bottom-up demands for entertainment," it constantly had to manoeuvre between party guidelines and the viewer's "thirst for cheap entertainment." 2 To meet these conflicting demands, programme designers made use of the fact that the medium was able to suggest an authenticity

1 Anikó Imre, TV Socialism, Durham 2016, 4.

2 Sabina Mihelj and Simon Huxtable, From Media Systems to Media Cultures: Understanding Socialist Television, Cambridge 2018, 9.

Ә Open Access. (C) 2021 Sebastian Lambertz, published by De Gruyter. (c) BY-NC-ND This work is licensed under the Creative Commons Attribution-NonCommercial-NoDerivatives 4.0 International License. https://doi.org/10.1515/9783110679151-005 
of the social reality on screen. They combined sound and image offering an incentive for people to inscribe themselves into the society they saw on screen. Thereby, a communicative space emerged, in which social issues and relations were frequently discussed. ${ }^{3}$ This space allows for a deeper analysis of the Party's efforts "to educate people in the spirit of Communism [. . .]" and to develop "the worldview, character, morality and culture of a future person of communist society" ${ }^{4}$ and how television viewers received and appropriated such efforts.

In this paper, I will take a closer look at this communicative space by analysing how workers who identified themselves as socialist workers communicated with Czechoslovak Television (ČST - Československá televize) in the 1960s and brought forward claims for entertainment within the daily programme. I will argue that their self-perception as a part of the ideological core group of socialism was the starting point for this claim and that the socialist regime - by trying to foster "New Socialist Men" powered by the regime itself, workers tried to make television actually one of their "own media", by basing their claims on the ideological construction of the New Man and by relating this to their everyday life, i.e. the hardship of their actual labour and the restraints of factory shifts. In the course of the 1960s, an argumentative shift can be observed towards an emphasis of the workers' role as television consumers. Letters to the makers of TV programmes thus became an avenue to stake claims for the cultural sovereignty of the people. This reveals a perhaps surprising space of this contest: television programmes and entertainment. In the context of limited parliamentary and public channels for participation, these became an important arena as alternative channels for claiming participation were not available.

Accordingly, this paper is also a contribution to one of the most frequent debates in connection with socialist societies of the $20^{\text {th }}$ century, namely the debate about individual agency. In light of the encompassing claim of Communist Parties to control the life of their citizens down to the last detail, socialist rule was widely perceived as totalitarian, i.e. denying people any scope of action

3 See: Kirsten Bönker, 'Fernsehkonsum, Zuschauerbeteiligung und politische Kommunikation der späten Sowjetunion', in: Uwe Breitenborn, Gerlinde Frey-Vor and Christian Schurig (eds.), Medienumbrüche im Rundfunk seit 1950, Cologne 2013, 199-217, here 200.

4 Martin Štoll, 1.5.1953. Zahájení televizního vysílání: Zrození televizního národa, Prague 2011, 183-184.

5 While the Czech form 'nový člověk' and the Russian 'novyj chevolek' are gender-free, the English-language literature on state socialism generally refers to the 'New Man'. In the following, the concept is used without a specific focus on gender. 
apart from retreating into private life or resistance. ${ }^{6}$ But as recent studies about the everyday reality in Czechoslovakia and other Communist states demonstrate, individual experiences were multifaceted and clearly reached beyond the easy classifications of "resistance", "retreat” or "opportunism." Rather, people had quite some space, within which they could influence their everyday life to a great extent. $^{7}$

The communicative space television offered can provide insights into how these negotiations proceeded and what the viewer's demands were based upon. An important role in this context played the idea of the socialist "New Man", an ideal of a person fully dedicated to the construction of a socialist society and thereby benefiting from its achievements. With this discursive figure, the Communist Party of Czechoslovakia (KSČ - Komunistická strana Československa) provided an opportunity to inscribe oneself into society and to develop the selfconception of an individual capable of acting with an awareness of both rights and duties. This self-conception, I will argue, could empower, among others, television viewers to demand an entertaining programme.

Studying non-democratic contexts, such as the Czechoslovak society in the 1960 s, it is widely held that television or radio audience functions only as a passive receiver of the top-down messages of propaganda. ${ }^{8}$ In contrast, state television also aimed to "model socialist citizenship"9 and "encourage popular participation in political affairs", ${ }^{10}$ which confronted the editors with an active, participative audience reacting to the various offers, television made, e.g. by asking for suggestions for future topics. ${ }^{11}$ Accordingly, they had to constantly

6 See e.g.: Pavel Kolář, 'Langsamer Abschied vom Totalitarismus-Paradigma: Neue tschechische Forschungen zur Geschichte der KPTsch-Diktatur', in: Zeitschrift für Ostmitteleuropaforschung 55 (2006), 253-275, here 255-256.

7 See e.g.: Stephen Kotkin, Magnetic Mountain: Stalinism as a Civilization, Berkeley 1995; Katherine Lebow, Unfinished Utopia: Nowa Huta, Stalinism, and Polish Society, 1949-56, Ithaca 2013; Mary Fulbrook, The People's State: East German Society from Hitler to Honecker, New Haven 2005; Muriel Blaive (ed.), Perceptions of Society in Communist Europe: Regime Archives and Popular Opinion, London 2019.

8 See: Darina Volf, Über Riesen und Zwerge: Tschechoslowakische Amerika- und Sowjetunionbilder 1948-1989, Göttingen 2016, 25-32.

9 Imre, TV Socialism, 33.

10 Mihelj and Huxtable, From Media Systems to Media Cultures, 26.

11 See: Irena Reifová, 'A Study in the History of Meaning-Making: Watching Socialist Television Serials in the Former Czechoslovakia', in: European Journal of Communication 30 (2015), 79-94, here 80 and Sabina Mihelj, Audience History as a History of Ideas: Towards a Transnational History, in: European Journal of Communication 30 (2015), 22-35, here 23 and 28. 
balance "the need to impose authority and the need to elicit involvement", ${ }^{12}$ in order to avoid any uncontrolled mobilisation of the audience. ${ }^{13}$ At the same time, this created a certain agency for the viewers, which even went beyond the "hermeneutical agency" Irena Reifová states for Czechoslovak viewers after 1968, who were capable to "generate interpretations [. . .] which significantly deviated from the intended propagandist meanings." 14

The individual agency of TV viewers will be analysed on the basis of the letters, the "Department for Audience Relations" (Odděleni pro styk s diváky) of Czechoslovak Television received. Founded in 1954, the Department was responsible for responding to such letters and for organising group discussion in factory clubs or culture centres, where mainly workers partook. From the very beginning of television broadcasting in Czechoslovakia in 1953, the editors in charge - and the Communist Party behind - enforced television viewers to state their opinion especially in written form, because they considered these letters also as an important source of information about the viewers themselves and about their everyday life. ${ }^{15}$ Additionally, regular telephone surveys were conducted from 1961, but on a daily basis not before $1971 .^{16}$

Letters to the television station were highly popular, in fact Czechoslovak Television became one of the most popular institutions to address a petition. In 1960, when the KSČ defined the „new tasks of Czechoslovak television“", ${ }^{17}$ the "Department for Audience Relations" counted 19.689 letters, from which 10.621 (54\%) related to prize competitions. One year later - the number of TV licenses had just reached one million - 43.977 incoming letters were recorded, in 1966 51.962 (46 \% concerned competitions). ${ }^{18}$ Many of these letters have been archived but in most cases only generally summarized in unsorted boxes, which makes it almost impossible to make explicit statements about the amount of archived

12 Stephen Lovell, 'Broadcasting Bolshevik: The Radio Voice of Soviet Culture, 1920s-1950s', in: Journal of Contemporary History 48 (2013), 78-97, here 94.

13 See: Imre, TV Socialism, 34.

14 Reifová, 'A Study in the History of Meaning-Making', 79-94, here 81.

15 See: Stefan Lehr, 'Pište nám! Dopisy diváků a posluchačů Československé televizi a rozhlasu', in: Marginalia Historica: Časopis pro dějiny vzdělanosti a kultury 3 (2012), 71-82, here 72. 16 This was done by the „Department for Audience Research“ in Prague (Pražský odbor výzkumu programu ČST a diváka v ČSR), see: Lehr, 'Pište nám!', 71-82, here 72 and Martin Franc and Jiří Knapík, Volný čas v českých zemích, 1957-1967, Prague 2013, 406.

17 Quoted after: Štoll, 1.5.1953. Zahájení televizního vysílání, 183-184.

18 Lehr, 'Pište nám!', 71-82, here 74. 
letters. For comparison only: In 1963, the Central Committee of the KSČ received 21.259 letters, its main newspaper, the „Rudé právo“ (The Red Justice), 32.866. ${ }^{19}$

Taken together, letters and reports about group discussions provided a clear picture of the audience's expectations: Entertainment. ${ }^{20}$ This was in sharp contrast to the ideas of the Communist Party, which tried to foster a "cultural-educational component" 21 on television and promoted "'higher forms' of recreation" 22 in order to prepare people to build socialism and become "New Men."23 So the discussion about the television programme - which was also one about the general question of how "New Men" should spend their leisure time - circulated around the dichotomy of (fictional) entertainment vs. (ideological) education and information.

Against this background, this chapter enquiries into the argumentative strategies workers writing to Czechoslovak television used when demanding what they considered an appropriate programme. These strategies can tell us more about how the educational efforts of the regime were interpreted and adopted as well as about the agency socialist workers claimed for themselves as part of their ideologically privileged position within socialist society.

\section{Socialist rule and the question of agency}

Studying agency under Socialism cannot omit terror, fear and repression a subject of discussion. ${ }^{24}$ However, "no political system, not even the communist dictatorship could work only by oppressing large parts of its population," 25 which means that all regimes had to try to secure people's favour by taking into account their wishes and needs. ${ }^{26}$ Hence, citizens living under socialist rule had a

19 National Archive of the Czech Republic (NA - Národní archiv), fund 02/4: KSČ - Ústřední výbor 1945-1989, Praha - sekretariát 1962-1966, volume 37, archive unit 71/3: Usnesení 71. schůze sekretariátu ÚV KSČ ze dne 12. května 1965.

20 See: Imre, TV Socialism, 8 and Mihelj and Huxtable, From Media Systems to Media Cultures, 12.

21 Martin Franc and Jiří Knapík, 'Getting Around to the Human Being in the Next Quarter: Leisure Time in the Czech Lands 1948-1956', in: Czech Journal of Contemporary History 1 (2031), 77-101, here 87.

22 ibid., 82.

23 See: Franc and Knapík, Volný čas $v$ českých zemích, 110 and 119.

24 Muriel Blaive, 'Introduction', in: Muriel Blaive (ed.), Perceptions of Society in Communist Europe: Regime Archives and Popular Opinion, London 2019, 1-12, here 2.

25 Matěj Spurný, Nejsou jako my: Česká společnost a menšiny v pohraničí (1945-1960), Prag 2011, 13.

26 See: Lehr, 'Pište nám!', 72. 
certain space for negotiation to improve their everyday life and to assert their entitlements. For Communist Czechoslovakia, such “a permanent negotiation process [. . .] between the regime and society" ${ }^{27}$ was located on various levels, as studies of Jaromír Mrňka and Matěj Spurný have already indicated. These studies illustrate "tensions and contradictory social and group interests" 28 and an arena of competing and conflicting, interrelated claims and practices, which were also an integral part of everyday life under Socialism.

Clearly any such negotiation is in sharp contrast to the theoretical principles of Socialism and Communism, which state that especially the final transition of society towards Communism had inevitably to be undemocratic. However, the negotiating power of individuals and social groups did not question socialist rule as such but rather contributed to its stability. The gap between ideological promise and lived reality opened up new possibilities for workers and other citizens to put forward popular claims towards the regime, "to make the best from this unequal and uneasy relationship"29 and to establish a "tacit minimal consensus." 30

An important part of the negotiations between the socialist state and its citizens was the idea of the "New Socialist Men" 31 and the regime's attempts to educate people to become one of them. The "New Man" was a largely ill-defined idea of how exemplary socialist citizens should behave and think. It came in different forms such as the "worker", the "communist" or the "socialist woman." Higher-order characteristics, which applied to all these categories, included a positive attitude towards the socialist system per se, towards the Soviet Union, the rejection of all that was "old" and "bourgeois" and the subordination of individual needs and interests to the common case of socialist construction. ${ }^{32}$ Building Socialism - and at some point Communism - was imagined to be the tasks

27 Blaive, 'Introduction', 4; Jaromír Mrňka, Svéhlavá periferie: Každodennost diktatury KSČ na př́kladu Šumperska a Žábřežska v letech 1945-1960, Prague 2015; Spurný, Nejsou jako my.

28 Blaive, 'Introduction', 4.

29 ibid.

30 See: Thomas Lindenberger, 'Tacit Minimal Consensus. The Always Precarious East German Dictatorship', in: Paul Corner (ed.), Popular Opinion in Totalitarian Regimes. Fascism, Nazism, Communism, Oxford 2009.

31 See: Denisa Nečasová, Nový socialistický člověk: Československo 1948-1956, Brno 2018; Peter Fritzsche and Jochen Hellbeck, ‘The New Man in Stalinist Russia and Nazi Germany', in: Michael Geyer and Sheila Fitzpatrick (eds.), Beyond Totalitarianism: Stalinism and Nazism Compared, New York 2009, 302-341.

32 See: Nečasová, Nový socialistický člověk, 11-14; Fritzsche and Hellbeck, 'The New Man in Stalinist Russia and Nazi Germany', 302-303. 
of socialist workers (men and women), ${ }^{33}$ who should distinguish themselves by constant, hard and diligent work. According to socialist ideology, this made the working class the vanguard of socialist construction and put them into an ideologically privileged position. ${ }^{34}$

From that position, workers - and other members of socialist society - were able to demand what they considered their rights and entitlements as "New Men." In this context, television played an important role. It offered new opportunities to educate and influence the audience, but also gave rise to the danger of an "uncontrolled, diffuse emotional mobilization." 35 So the implication of the medium preceded mainly "by trial and error," 36 and many Party officials struggled to value television and degraded it to a "light" medium of mass culture. All this provided for a lively discussion about the social order, power structures and social coexistence ${ }^{37}$ and which gave viewers certain "leverage in defining the medium's development."38

\section{Workers demanding entertainment}

One of the issues viewers most frequently addressed was the relation between their expectation of an entertaining and relaxing programme and the amount of political and ideological education and information on screen. From the first broadcast on, this was a constant dispute, not only between the public broadcasters but also between the Party and the editors in charge who had recognized the audience's desire for light entertainment. Editors had to navigate between the viewer's demands and the Party's wish for a more cultural and educating programme. ${ }^{39}$

Lacking any sound experience with the medium, programme designers had to vastly experiment in the early days of Czechoslovak Television. According to

33 On women's role as builders of Socialism see: Denisa Nečasová, Buduj Vlast - Posíliš míř! Ženské hnutí v českých zemích 1945-1955, Brno 2011.

34 Kevin McDermott: 'Popular Resistance in Communist Czechoslovakia: The Plzeň Uprising, June 1953', in: Contemporary History 20 (2010), 287-307, here 290-291.

35 Imre, TV Socialism, 34.

36 Kristin Roth-Ey, Moscow Prime time: How the Soviet Union Built the Media Empire That Lost the Cultural Cold War, Ithaca 2011, 179 and Miloš Smetana, Televizní seriál a jeho paradoxy, Prague 2000, 23.

37 See: Bönker, 'Fernsehkonsum, Zuschauerbeteiligung und politische Kommunikation', 200.

38 Imre, TV Socialism, 10.

39 See: Franc and Knapík, Volný čas $v$ českých zemích, 408. 
Martin Štoll early programme consisted of televised theatre shows, feature films, film novellas, puppetry, animation, political films, sports news, children's programmes, concerts, ballets, singing or dance performances, popular scientific and educational programmes, great music-hall and satirical evenings and a lot of other minor programmes. In general, the programme was structured along the many socialist and non-socialist anniversaries and viewers could expect an attractive programme at Christmas or New Year's Eve. ${ }^{40}$

Educational programmes gained significance only by the mid-1950s. In 1956, a regular news programme and the "Television University" (Televizni univerzita) were launched, a programme, which should introduce its viewers to MarxistLeninist philosophy as well as science and other subjects. But although the KSČ-officials aimed at an "educational and cultural programme", ${ }^{41}$ the popularity of television depended greatly on the entertainment programme, now consisting also of quiz and music shows or full-length estrades. ${ }^{42}$

Viewer's expectations were particularly high when it came to holiday programmes, e.g. Christmas or New Year's Eve. On these days, the usual programme was abandoned in favour of special programmes, mainly "to create a sense of extraordinary occasion [. . .] and celebrate the ongoing movement towards the communist future." ${ }^{43}$ Such programmes - especially on non-communist, i.e. traditional, holidays - openly aimed at entertaining the audience which was why it was extraordinarily popular. On the other hand, the disappointment was even higher, when television failed this task.

One example of this is the debate about the New Year's Eve programme of 1962/1963. Several viewers bemoaned that what had been promised as a "sensational New Year's Eve"44 turned out to be "rubbish." ${ }^{45}$ If one can believe the viewer's descriptions, the programme was a combination of dancing performances,

40 See: Franc and Knapík, Volný čas v českých zemích, 404; Martin Štoll, Television and Totalitarianism in Czechoslovakia. From the First Democratic Republic to the Fall of Communism, New York 2019, 145; Mihelj and Huxtable, From Media Systems to Media Cultures, 261-263.

41 Franc and Knapík, Volný čas v českých zemích, 404 and 424; Štoll, 1.5.1953. Zahájení televizního vysílání, 156.

42 See: Štoll, ibid.

43 Mihelj and Huxtable, From Media Systems to Media Cultures, 261.

44 Archive and Programme Funds of Czech Television (APF ČT - Archiv a programové fondy České Televize), box 134, Inf 869, Dopisy diváku: Letter from Helena F., Humpolec, January $23^{\text {rd }}$ 1963.

45 APF ČT, box 134, Inf 869, Dopisy diváku: Letter from Dr. Vladimír M., Prague, January $23^{\text {rd }}$ 1963. 
musical numbers ${ }^{46}$ and comedy shows ${ }^{47}$ with the negative highlight of "girls [dancing] on a graveyard." ${ }^{48}$ After a first wave of criticism shortly after New Year's Eve, the editors themselves broadcasted a short statement, in which they apologized for having disappointed the audience and asked for suggestions for improvement. With the didactic play of socialist "self-criticism" - the admission of a mistake followed by constructive ideas and suggestions ${ }^{49}$ - the editors themselves triggered a second wave of criticism, this time more constructive. This demonstrates the viewer's desire to participate and to actively interact and signifies the ideological importance of such letters to television.

In their letters responding to the programme the authors made quite clear that their expectations had been disappointed. For example, a viewer from a small Moravian village wrote: "After a long day of work, in the evening we are looking forward to nice entertainment when lying in bed. Yes, entertainment! Unfortunately, there was none [. . .]." ${ }^{50}$ In a similar way, a viewer from Mláda Boleslav voiced his criticism about the, in his view, "historical New Year's Eve in the year of the Lord 1962 a.C.!!!”: “[. . . ] if anyone stayed home, and that was the absolute majority - then he or she simply expected to be entertained the whole evening!!! and (sic!) not only for a while."51

Such demands ran through the majority of the letters to the ČST, not only with regard to holiday programmes. ${ }^{52}$ When writing to the different editorial departments, the authors did not present themselves as humble supplicants but as citizens or rather television viewers with a clear sense of entitlement and expectations. Obviously the narrative of letters to be found in the archives of Czechoslovak Television differed from those addressed to institutions such as the

46 APF ČT, box 134, Inf 869, Dopisy diváku: Letter from Pavel Š., Vrbno, January $26^{\text {th }} 1963$ and letter from an anonymous author, Prague, January $2^{\text {nd }} 1963$.

47 APF ČT, box 134, Inf 869, Dopisy diváku: Letter from Jiři H., Prague, January $2^{\text {nd }} 1963$.

48 ibid.

49 In detail see: Jonathan L. Larsson, 'Deviant Dialectics: Intertextuality, Voice and Emotion in Czechoslovak Socialist Kritika', in: Petr Petrov and Lara Ryazanova-Clarke (eds.), The Vernaculars of Communism: Language, Ideology and Power in the Soviet Union and Eastern Europe, New York 2015, 130-146 and Oleg Kharkhordin, The Collective and the Individual in Russia: A Study of Practices, Berkley 1999.

50 APF ČT, box 134, Inf 869, Dopisy diváku: Letter from Ferdinand N., Zvole u Zábřeha, undated (emphasis in original).

51 APF ČT, box 134, Inf 869, Dopisy diváku: Letter from Joseph D., Mláda Boleslav, January $28^{\text {th }}$, 1963 (emphasis in original).

52 For this section I analysed one box with letters explicitly answering to the New Year's Eve programme. Letters archived in other boxes show similar patterns. See eg.: APF ČT, box 119, Inf 583, Ohlas diváků na nedokončenou estrádu „Sejdeme se na Štvanici“ or box 120, Inf 587, Zamítnuté náměty pro „Sedmero prání.“ 
Central Committee of the KSČ or the office of President that would often receive requests of helpless victims demanding justice. ${ }^{53}$ However, the extent to which viewers expressed pointed demands demonstrates the importance of television as a means of communication.

In order to justify their demands for entertainment and relaxation, viewers writing to Czechoslovak Television inter alia referred to their self-understanding as "socialist workers", which - from their point of view - included the opportunity to relax as a compensation for the hardship of everyday work:

I would like to ask the programme designers to take into account those who mostly watch TV on Saturday evening. Mainly, these are workers, who cannot sit in front of a TV on working days, not because they are not interested, but who because of their occupation primarily watch TV on Saturday evening. ${ }^{54}$

In the same or a similar way, many authors argued. They presented an account of their work and their achievement to stress their entitlement to an entertaining programme, which should help to forget the troubles of the working day: "We understand that people have different tastes and you want to meet everyone's taste, but do not try to convince us that people do not want to be entertained after work." 55 Or, as a viewer from the industrial city of Gottwaldov put it:

I think that television is there for entertainment, that is why I, on behalf of the majority of the audience, ask to include more entertainment (and less work) on television, more such programmes as on Saturday and our satisfaction will be greater. ${ }^{56}$

Connecting everyday labour with a claim for entertainment, these examples show how the self-perception of being part of the working class, socialism's vanguard, could empower people to word claims towards the regime and its representatives. Their authors did not consider being a worker only as a form of self-realisation, as the socialist ideology saw it. Rather, industrial workers saw their identity as a way to facilitate a reward, i.e. entertainment and relaxation.

53 See: Sheila Fitzpatrick, 'Supplicants and Citizens: Public Letter-Writing in Soviet Russia in the 1930s', in: Slavic Review 55 (1996), 78-105, here 81-83.

54 APF ČT, box 134, Inf 869, Dopisy diváku: Letter from Stanislav N., Šumperk, January $26^{\text {th }}$, 1963.

55 APF ČT, box 119, Inf 583, Ohlas diváků na nedokončenou estrádu „Sejdeme se na Štvanici“: Letter from the employees of the national enterprise „Transporta“, Chrudim. September $3^{\text {rd }}, 1959$. 56 APF ČT, box 120, Inf 584, Dopisy divákủ k pořadu „Lod’ splněných pránini“: Letter from Olina F., Gottwaldov, July $19^{\text {th }}, 1959$. 
So Television viewers reinterpreted the privileged position they had been assigned by the regime ${ }^{57}$ and took it as a starting point for their demands.

In conjunction with the influence of television - the number of licences reached the number of one million in $1961^{58}$ - the demands of the audiences grew and the viewer's criticism became sharper: "As you know, workers want to be entertained on television, to have a rest after a long day of work and live at least a bit of a cultural life, however, the television programme is below grade [. . . ]."59 In addition, it was taken for granted that the programme directors had the same intention: "Please consider my few remarks and suggestions only as the opinion of one of those who [. . . ] are interested that our television still fulfils our expectations better: in the case of New Year's Eve this is to bring joyful comfort to our homes."60

In all of these cases it was especially workers, ${ }^{61}$ who claimed sovereignty in and over their free time and succeeded in influencing the making of TV programmes. Their argument centred on the presumed privileged position within society, which had been assigned to them directly by the Communist Party and which they affirmed by referring to their work performance as the criterion of a true socialist worker. ${ }^{62}$ As socialist workers, in turn, they raised a claim for entertainment and relaxation. This illustrates that the authors had developed a very own interpretation of the rights and obligations of the working class and that they took their self-perception as socialist workers as a basis of empowerment.

Beyond that, some authors compared their actual job to the work of television employees and in this way stressed the salience of socialist categories for individuals trying to describe their social reality:

For you, though, for whom the creation of cultural programmes, humorous and satirical films etc. is an essential occupation, in production would be no excuse for similar rejects. Quite the contrary - in such a case you would be subject to the strictest criticism and just as every shop floor worker, according to socialist principles would have the right to remuneration corresponding to the quality and the amount of the work you are presenting soci-

57 See: Nečasová, Nový socialistický člověk, 77-79.

58 See: Štoll, 1.5.1953. Zahájení televizního vysílání, 178.

59 APF ČT, box 134, Inf 869, Dopisy diváku: Letter from the employees of ČSAO, Prague, January $7^{\text {th }}, 1963$.

60 APF ČT, box 134, Inf 869, Dopisy diváku: Letter from Oldřich B., Prague, January $25^{\text {th }}, 1963$.

61 Of course not only workers were writing. The authors of letters to Czechoslovak Television formed a heterogeneous, diverse group from all sections of society, e.g. academics, officials or pensioners.

62 See: Nečasová, Nový socialistický člověk, 75-124 
ety. For the above-mentioned reasons it is clear that for you such principles do not hold true, because in such a case your delight about a great New Year's Eve would be at least like ours. ${ }^{63}$

In this example it is obvious that the authors - a worker's collective from Prague not only transmitted the demands of their own profession to the work carried out by television employees but also determined a hierarchy in which television was nothing but a service for those building socialism. This underlines that under socialism, large strata of the workforce felt their daily work valued and conceived an inherent awareness for its high importance within the greater context of socialist construction. ${ }^{64}$ It was an opportunity to actively contribute to the construction of a better society and thus could ascribe meaning to people's lives. On the downside, however, a feeling of devaluation regarding work could evoke a great deal of outrage and disappointment, which television viewers expressed for example after the New Year's Eve of 1962/63.

Consequently, the work television viewers had done themselves served as the main criterion for evaluating the television programme. This was the benchmark all other work had to correspond to, especially the programme on television, which should act in accordance only with the audience's demands for entertainment. Again and again, viewers demanded that the programme should be controlled just as the "products of every worker" 65 and that the "culprit is punished according to the resulting damage."66

As these examples show, the overall orientation (too much education, too little entertainment) of the television programme and especially the highly anticipated New Year's Eve show were more than a constant source of frustration for the audience. Many television viewers considered its poor quality as a blatant injustice, because they had the impression that the employees of Czechoslovak Television could permit themselves mistakes, ordinary workers would have been punished for. This resulted in the feeling that their own work was

63 APF ČT, box 134, Inf 869, Dopisy diváku: Letter from the employees of AZL Letnany, Prague, January $7^{\text {th }}, 1963$.

64 See: Peter Heumos, 'State Socialism, Egalitarianism, Collectivism: On the Social Context of Socialist Work Movements in Czechoslovak Industrial and Mining Enterprises, 1945-1965', in: International Labor and Working-Class History 68 (2005), 47-74.

65 APF ČT, box 134, Inf 869, Dopisy diváku: Letter from the employees of AZL Letnany, Prague, January $7^{\text {th }}, 1963$.

66 APF ČT, box 134, Inf 869, Dopisy diváku: Letter from the factory committee of the unified trade union (ROH) ČZG, Prague, January $2^{\text {nd }}, 1963$. 
depreciated, when television presented "scrap material" 67 to its viewers. In this manner, those who wrote to Czechoslovak Television or expressed their opinion in surveys among viewers - that also produced a high degree of criticism-, demonstrated that their everyday work was crucial for their self-perception, which in turn built upon the appreciation of that work by the socialist regime. So in the end, the regime itself had empowered its citizens to demand appreciation, equality and privileges they had been promised.

In the wake of this, some television viewers even began to argue that also the programme structure should be aligned according to their requirements, which meant that the programme designers should take into consideration the working hours of the shift workers. In the planned economy of Socialism, the working day was structured according to macroeconomic aspects, so that in every factory the employees worked in the same three shifts. According to the reports of the "Department for Audience Relations", such claims about the adjustment of broadcasting times to that scheme were formulated regularly. In December 1961, for example, the programme "Conscience in revolt" (Vzpoura svědomí) - a serial about a German soldier of the Second World War, who after the war first becomes a Soviet prisoners of war and is later confronted with the good life of some Nazi war criminals in the American Zone of Occupation - was described as the most popular programme. However, the third episode was criticized, because some of the viewers could not watch it due to its transmission time, which intersected with the second and third shift. ${ }^{68}$ Furthermore, surveys about audience habits revealed recurrent demands for a review of broadcasting times colliding with shift work. These demands were articulated especially in connection with series, as workers were often unable to follow all episodes. Apparently, the viewers conceived of this practice as a certain "indifference of television towards the needs and claims of the second shift." 69

These examples display a process of negotiation between the working class audience and the editors in charge, who in turn were under surveillance of the Party. ${ }^{70}$ The monthly reports on audience reaction reflected not only the major criticism the viewers voiced. The reports also provided detailed internal discussions about how to meet that kind of criticism. Unfortunately, the existing archival

67 APF ČT, box 134, Inf 869, Dopisy diváku: Letter from the factory committee of the unified trade union (ROH) ČZG, Prague, January $2^{\text {nd }}, 1963$.

68 APF ČT, box 128, Inf 763, Report „Pořady měsíce prosince 1961 v ohlase diváků“, 3.

69 ibid.

70 See: Irena Reifová, 'Kleine Geschichte der Fernsehserie in der Tschechoslowakei und Tschechien', in: Forschungsstelle Osteuropa an der Universität Bremen (ed.), Kommerz, Kunst, Unterhaltung: Die neue Popularkultur in Zentral-und Osteuropa, Bremen 2002, 161-184, here 165. 
documentation does not contain any material about whether or to what extent measures have been taken, but the reports clearly show that remarks of the audience have been analysed and taken seriously. For instance, the report for October 1961 draws the following conclusion from discussions with viewers in different companies:

Broadcasting times are unsuitable for those viewers, who are working in an operation with three shifts. They [the viewers, S.L.] propose that programmes, which are intended to be the main programme of an evening, normally start at $7.30 \mathrm{pm}$ or even before. [. . .] [F] rom Saturday programmes they expect more entertainment and distractions than television offers so far. ${ }^{71}$

All these examples show very clearly that remarks and complaints from television viewers had a real impact on the considerations of the editors in charge, especially when workers mobilised their working conditions. In accordance with the special significance the working class had within socialist ideology, workers obviously had a great deal of influence when it came to the programme design of Czechoslovak Television. At this point, workers were able to use an ideological shaped language to gain an active agency.

\section{The working class between the Kafka conference and the Prague spring}

Besides the conviction to be part of society's vanguard, the worker's agency within the field of television and leisure time depended to a great extent on the communicative space television offered. This space in turn correlated with the country's political climate, which over the course of the 1960 s was subject to change. Especially the year of 1963 can be seen as a turning point for workers' agency.

1963 was not only the year, when literary scholars met in the small Slovak town of Liblice to discuss the writings of Franz Kafka. It was also the year when the economic crisis the country had been facing for several years went public, which called into question the core of the ideological promises of a better future for the working class. ${ }^{72}$ With its discussion if "alienation" could at all exist in a

71 APF ČT, box 128, Inf. 763, Pořady měsíce ř́jna 1961 v ohlase diváků: Besedy s televizními diváky, 1.

72 See: Kevin McDermott, Communist Czechoslovakia, 1945-89: A Political and Social History, New York 2015, 107. 
socialist society, the Kafka conference addressed popular concerns and needs in this context and thus deconstructed a common set of basic ideological values. ${ }^{73}$ Even devoted communists struggled to believe in all the Party's promises and assurances of a better society. The Kafka conference in this way impacted greatly on the communication between the regime and its citizens, which to a great extent was performed via television. As the conference addressed subjects and thus corresponded to people's everyday experiences letter writers anticipated that Party and State finally took their concerns seriously. As a result, they made even higher demands on what was offered to them seeing a chance to enforce their own idea of Socialism.

But in spite of the persistent economic crisis, these letters did not centre on economic or social hardship, but displayed a higher educational level and rising expectations regarding quality of life and consumption. All this resulted from the politics of "socialist consumerism," established after the disastrous consequences of the currency reform of $1953 .^{74}$ Along this line, the growing demands that had already come to the fore in earlier letters to Czechoslovak television and other institutions such as the radio became even more demanding. They extended beyond the supply of daily goods, and concerned luxury goods such as motorcycles. $^{75}$

As the already high demands of the TV audience increased further, most viewers had no doubts that television had to serve first and foremost their interests and to bring "relaxation and entertainment." that they did no longer include only general demands for more entertainment, but more references to specific content that would meet these expectations. A worker's collective from Slovakia, for example, specified a list of entertaining programmes such as "old Czech films"77 that would fulfil their needs when they would "sit down in front of it [the TV-set, S.L.] after a long day of work in order to [. . .] relax." 78

It was also popular to relate the television programme to the country's economic situation. In 1965, for instance, a viewer working in metallurgy criticized

73 See: Martin Schulze Wessel, Der Prager Frühling: Aufbruch in eine neue Welt, Stuttgart 2018, 57-67.

74 McDermott, Communist Czechoslovakia, 1945-89, 107.

75 See for example: Archival and programme funds of Czech Radio (AČRo - Archivní a programové fondy Českého rozhlasu), Svodka $z$ dopisů posluchačů Čs. rozhlasu za července, srpen a listopad 1961.

76 APF ČT, box 113, Inf 490, Bulletin z dopisů diváků, 31. července-28. srpna 1965, 7.

77 APF ČT, box 156, Inf 926, Dopisy diváků: Letter from a worker’s collective, Myjava, April $22^{\text {nd }}$ 1965.

78 ibid. 
a recital which should take care of "entertaining television viewers", but failed to do so. He referred to a campaign developing "[n]ew forms of control in [. . . ] national economy" and wondered that "in such times one has to watch such a programme."79 Just as the viewers criticizing the New Year's Eve programme a few years before, he was disappointed about the fact that television did not take the worker's problems seriously and considered this as a devaluation of his own work.

However, comparisons between these letters and earlier examples reveals that fewer authors formulated their claims as members of the working class or with referring to their contribution to socialist construction. Rather, they appeared primarily as television viewers - and basing their claims on a new pattern of argumentation, i.e. being consumers and owners ("A TV-set is a big investment for all of us"). ${ }^{80}$ In this role they were convinced of their right to demand a good programme, as such a programme signified a higher standard of living. Some showed a certain astonishment about the "indigestible" programme, despite of "so many theatres, cabarets etc." ${ }^{81}$ Others took the view that Czechoslovak Television had "a lot of money" to take into account "also the interests of the audience." 82

This changing sense of entitlement of television viewers can also be related to a changing role of the institution itself within the power structure of the Czechoslovak socialist regime. With the appointment of Jiři Pelikan as the new head of Czechoslovak Television in 1962 the programme was adjusted to the demands of the Communist Party - which meant further educational programmes, above all. ${ }^{83}$ However, television began to develop the self-image of a partially independent institution, which was bound by the obligation to criticize grievances within socialist construction, even though it was in fact obliged to the Party. ${ }^{84}$

It was especially younger screenplay writers, whose ideas of creative work came into conflict with the Party's guidelines. While Party officials preferred a programme, which depicted an idealised socialist reality with model individuals in an ideal socialist society, many authors committed to the idea of authenticity and aimed to present life as it really was. This self-image resulted in increasing

79 APF ČT, box 156, Inf 926, Dopisy diváků: Letter from M. Č. and M. H., Vilémov, March $29^{\text {th }}$, 1965.

80 APF ČT, box 156, Inf 926, Dopisy diváků: Letter from a worker’s collective, Myjava, April $22^{\text {nd }}$, 1965.

81 APF ČT, box 113, Inf 490, Bulletin z dopisů diváků, 31. července-28. srpna 1965, 3.

82 APF ČT, box 113, Inf 490, Bulletin z dopisů diváků, 31. července-28. srpna 1965, 17.

83 See: Franc and Knapík, Volný čas v českých zemích, 405.

84 See: Štoll, 1.5.1953. Zahájení televizního vysílán, 184. 
criticism towards state and party institutions and representatives, especially when television viewers applied to editorial staff with their everyday problems.

Moreover, a generally decreasing importance of the working class in Communist Czechoslovakia can be stated. While initial debates on political, economic and scientific reforms after 1963 had allowed for criticism and improvement proposals and the general perception of being part of a privileged group had empowered workers to comment on societal development, the role of the working class within the Czechoslovak version of socialism began to change. Although many reformers still emphasised that "in the end, the workers decide the fate of the country," 85 and thus stressed popular sovereignty, this ideological leadership was put increasingly into question. In the view of the "scientific and technical revolution", which had been declared for the first time at the $22^{\text {nd }}$ conference of the Communist Party of the Soviet Union (CPSU) in 1961, it was rather engineers and scientists, who should ensure progress. With the Prague Spring being mainly a project of intellectuals, ${ }^{86}$ the privileged position of the working class at least suffered certain cracks. In consequence, this ideological shift weakened the agency that could be obtained by referring to a self-conception as socialist workers.

At the latest, the Soviet invasion in August 1968 put an end to all efforts of the working class to gain agency in one way or another. The tightened regime of the so-called "normalisation" (normalizace) took back most of the reforms established during the Prague Spring and tried to "normalise" society, which meant to take back control and to narrow down most of the existing space for negotiation reaching well beyond the reforms of 1968. Television provided a central tool in consolidating the country's socialist order by reflecting popular ideas of a "good life" and depicting a vision of how to achieve it. ${ }^{87}$ To enforce such visions of the "calm life" 88 the regime had promised its citizens, television came under the full control of the regime, a step by which most of the viewer's opportunities to make an impact were restricted.

85 Oldřich Švestka, ‘Otázky dělnické politiky’, in: Rudé právo, July $14^{\text {th }}$ (1968), 1-2.

86 See: Schulze Wessel, Der Prager Frühling, 67-68 and 188.

87 See: Paulina Bren, The Greengrocer and His TV: The Culture of Communism after the 1968 Prague Spring, Ithaca 2010, Reifová, 'A Study in the History of Meaning-Making', 79-94, here 81.

88 See: Michal Pullmann, Konec experimentu: Přestavba a pád komunismu v Československu, Prague 2011. 


\section{Conclusion}

Although the reform movement of the 1960s first and foremost signified a loss of importance for socialist workers within Czechoslovak society, this demonstrates at the same time, how much agency they had had before. Empowered by the regime, which devoted a lot of energy to the education of "New Socialist Men", workers disposed of agency in three different forms. First, making use of socialist ideology they claimed sovereignty as workers being the driving force of society. Second, referring to their daily hardship in manual labour they demanded entertainment. Third, towards the 1960s television viewers developed a sense of consumerism having made a significant investment for their TV-sets.

In this context, television was a field, which offered ideal conditions for this agency coming to light. Stuck between the requirements of the Party and the claims of the audience, programme designers had to constantly make compromises, which gave the viewers a lot of leverage to push their wishes through. They acted as an active audience, which obviously existed also under nondemocratic regime, and actively engaged with the different offers, television made by complying with the request "to (self-)educate in ways that were community-orientated." ${ }^{89}$ For obvious reasons, wishes expressed in such viewers' letters did not relate directly to the political or social order, but touched upon ideological coordinates in their own way, as television and leisure time in itself were key aspects of political education. As a consequence, the Party could definitely not ignore these demands.

It is most remarkable that the worker's agency or bargaining power was derived from exactly the regime's educational efforts television was part of. As the argumentative patterns in letters to Czechoslovak Television show, the authors gratefully accepted the idea of the "New Man", but often interpreted it in their very own way. Being a socialist worker - one of the central manifestations of the "New Man" - not only meant to see one's work adequately appreciated, but also to have the opportunity or even the right to make certain demands, quasi as a form of remuneration. By arguing in this fashion, workers performed a great deal of interpretative power regarding a key aspect of socialist ideology.

This is reflected in many ways. While some authors just stated that they expected to be entertained after a long working day or week, some went even further and requested that the television programme should be subjected to the same criteria as their work. With this comparison, they demonstrated a strong awareness of their own - ideological attributed - position within society. This

89 Imre, TV Socialism, 39. 
awareness became apparent also in the self-confident manner, many workers demanded that broadcasting times should be modified according to the work hours of shift work. Convinced to be the most important part of socialist society they did not ask humbly if the editors in charge could take their wishes into consideration, but openly demanded a programme, which should serve only their needs and wishes.

With these wishes referring to an entertaining and amusing and not, as intended by the Party, cultural and educational valuable programme, they demonstrated once again the potential influence television viewers and especially workers had towards a regime which claimed for itself to control its citizens in all aspects of life and to act against their will, if necessary. Here it becomes clear that the regime's sovereignty was far from being absolute but could be challenged in a number of ways. Demanding self-determination about one's own leisure time as members of the working class was a feasible and successful way. 